\title{
Attitude of Farmers towards Crop Diversification
}

\author{
L. Mohammed Ghouse ${ }^{1 *}$ and S. Nazreen Hassan ${ }^{2}$ \\ ${ }^{1}$ Department of Social Sciences, Agricultural College and Research Institute, \\ Killikulam, Tamil Nadu, India \\ ${ }^{2}$ Krishi Vigyan Kendra, Thiruppathisaram, Kanyakumari, Tamil Nadu, India \\ *Corresponding author
}

\section{A B S T R A C T}

\begin{tabular}{|l|}
\hline Ke y w o r d s \\
Crop \\
diversification, \\
Attitude of farmers, \\
Tirunelveli district, \\
Tamil Nadu
\end{tabular}

This paper analyzes the attitude of farmers towards crop diversification in Tirunelveli district of Tamil Nadu. Census of India (2011) reported that about 54.60 per cent of the population involved in agriculture and allied activities. The total food grains production in the country was 284.83 million tons during the year of 2017-18. Crop diversification is one of the best options to increase income of the farmers and also leads to food, nutritional and ecological security. It helps in eradication of poverty by providing employment opportunities. In Sub Sahara Africa, crop diversification is used as an important strategy to increase income, reduce risk and able to grow wide range of crops in a given area. In 2004, Zambia was affected severely by several drought cycles. Government of Zambia promoted crop diversification with the objective to increase food security and nutrition status of farm households. In India, after Green revolution, there is continuous rush for diversified agriculture in terms of crops. Indian agriculture shifted towards non-cereal crops in order to increase the income and agricultural sustainability. This paper concludes that nearly three fourth of the farmers had moderately favorable attitude towards crop diversification.

\section{Introduction}

In India, small farm sizes characterize agriculture. The average farm size is about 1.57 ha. About 93 per cent of the farmers have farm size smaller that 4 ha. They contribute about 55 per cent of total cultivable land. Only 1.6 per cent of farmers having farm size of more than 10 ha and they contribute about 17.4 per cent of total cultivable land. Economic survey of India in 2017-18 computed crop diversification through crop diversification index (CDI) for all states in India during the years 1994-95, 2005-06 and 2014-15 to know whether there was any change in cropping pattern or not. It was found that the states like Chattisgarh, Haryana, Madhya Pradesh, Odisha, Punjab and Uttar Pradesh faces a decline in crop diversification index (CDI). Among these states, Odisha has a major decline in crop diversification index (CDI). It was 0.743 in 1994-95, 0.73 in 2005-06 and it reduces to 0.340 in 2014-15. Two of the states, Himachal Pradesh and Jharkhand have shown increasing trend in crop diversification index 
(CDI). Other state remains stable and not shown major change. Overall India, crop diversification index (CDI) remains stable throughout the periods. Tamil Nadu state economy depends on agriculture. It contributes about 13 per cent to the state income. Almost 56 per cent of population in the state depends on agriculture. In Tamil $\mathrm{Nadu}$, the share of important cereal crops like paddy, groundnut, cholam has decreased over the years. At the same time, share of minor crops like maize, black gram, green gram, coconut, fruits and vegetables has increased over the years. This shows that the state was moving from crop specialization to crop diversification.

The main objectives of this study include to study the attitude of farmers towards crop diversification among the selected respondents.

Rajanna et al., (2009) revealed that majority of the respondents (51.00 per cent) were found to have favourable attitude towards sustainable farming system, while 24.00 and 25.00 per cent of the farmers were found to have unfavourable and neutral attitude towards sustainable farming system respectively.

Singh et al., (2012) concluded that majority (41.05 per cent) of the farmers were found to have favourable attitude towards agricultural diversification, followed by 39.28 and 19.65 per cent possessed unfavourable and neutral attitude towards agricultural diversification, respectively.

Samah et al., (2012) reported that more than half of the respondents (58.60 per cent) possessed favourable attitude towards sustainable agriculture, followed by 36.50 and 4.90 per cent of the respondents were found to have medium and low level of attitude towards sustainable agriculture respectively.
Goswami (2016) reported that majority of the respondents (40.80 per cent) had medium attitude category, followed by 36.70 per cent and 22.50 per cent of them had more and less favourable attitude towards scientific fish culture.

Rajan et al., (2016) revealed that more than half of the respondents (64.45 per cent) were found to have low level of attitude regarding fish production technology, followed by 23.34 and 12.21 per cent of them had medium and high level of attitude regarding fish production technology respectively.

\section{Materials and Methods}

The study was based on the primary data collected among the selected respondents. A sample size of 120 farmers was fixed as respondents. The 120 respondents were identified from the selected six villages from three blocks by applying proportionate random sampling method. The attitude of any person towards his occupation largely decides his type of involvement on a continued basis. This was applicable to farmers and too relevant for the present study which was considered as highly risk oriented and difficult to continue. A scale was developed for this study to measure the Attitude of farmers towards crop diversification. A five point continuum of 'strongly agree', 'agree', 'undecided', 'disagree' and 'strongly disagree' was used as response categories. Following scoring procedure was adopted for this study.

The scores obtained for each statement was summed up to obtain the attitude score for an individual respondent. The scores (maximum) to 11 (minimum). Maximum score revealed a favourable attitude, while a minimum score indicates unfavourable attitude of farmers towards crop diversification (Table 1). 


\section{Results and Discussion}

Attitude refers to the degree of favourable or unfavourableness towards some psychological object. The psychological object in the present study was crop diversification. The distribution of respondents based on the attitude of farmers towards crop diversification was presented in the table 2 .

It could be seen from the table 2, that nearly three fourth of the diversified growers $(75.80$ per cent) had moderately favourable attitude towards crop diversification followed by 15.90 per cent of the diversified growers who had highly favourable attitude towards crop diversification and the remaining 8.30 per cent of the diversified growers had less favourable attitude towards crop diversification. Majority of the farmers had medium level of innovativeness and scientific orientation, this might be a reason for moderately favorable attitude of farmers towards crop diversification.

Table.1 Scoring procedure to measure attitude of farmers

\begin{tabular}{|l|c|c|c|c|c|}
\hline Response & Strongly agree & Agree & Undecided & Disagree & $\begin{array}{c}\text { Strongly } \\
\text { disagree }\end{array}$ \\
\hline Scores for positive statements & 7 & 5 & 4 & 3 & 1 \\
\hline Scores for negative statement & 1 & 3 & 4 & 5 & 7 \\
\hline
\end{tabular}

Table.2 Distribution of respondents according to their attitude towards crop diversification

\begin{tabular}{|l|l|l|l|}
\hline S. No & Categories & \multicolumn{2}{|c|}{ Diversified Farmers $(\mathbf{n}=120)$} \\
\cline { 3 - 4 } & & Number & Per cent \\
\hline 1. & Less favourable attitude & 10 & 8.30 \\
\hline 2. & Moderately favourable attitude & 91 & 75.80 \\
\hline 3. & High favourable attitude & 19 & 15.90 \\
\hline & Total & 120 & 100.00 \\
\hline
\end{tabular}

From the above discussion, It was evident that nearly three fourth of the diversified growers (75.80 per cent) had moderate favourable attitude towards crop diversification. From the findings derived in this study, certain broad implications have been brought out. This might be useful in formulating strategies for increasing crop diversification practices in the study area. The study revealed that the farmers differed widely in their socio economic characteristics and majority of them had low level of Social participation and medium farm size ranging from 2.5 ha to 5 ha farm size. This finding stresses the importance of bringing the farmers to the mainstream by participating in social and community activities. It was also found that most of the farmers had medium level of innovativeness and medium level of Information source utilization which shows that efforts can be made to intensify extension efforts by narrowing down the farmers' extension ratio in the state department.

\section{References}

Goswami, B. (2016). Factors Affecting Attitude of Fish Farmers towards Scientific Fish Culture in West Bengal. Indian Research Journal of Extension Education, 12(1), 44-50.

Rajan, P., Dubey, M. K., Singh, S. R. K., and Khan, M. A. (2016). Factors affecting knowledge of fish farmers regarding 
fish production technology. Indian Research Journal of Extension Education, 13(2), 126-127.

Rajanna, N., VijayaLaxmi, K. G., Lakshminaryan, M. T., and Chandregowda, K. N. (2009). Attitude of paddy farmers towards sustainable farming practices. Mysore Journal of Agricultural Sciences, 43(3), 522-526.

Samah, B. A., D'Silva, J. L., Shaffril, H. A. M., Man, N., and Azman, A. (2012).
Malaysian contract farmers' attitude towards sustainable agriculture. $J$. Basic. Appl. Sci. Res, 2(9), 9205-9210.
Singh, R. A., Singh, I. P., Jitendra, S., Rajesh, R., Dharmendra, Y., and Singh, J. P. (2012). Farming system approach is a path of prosperity for ruined farm families. Agriculture Update, 7(3/4), 292-294.

\section{How to cite this article:}

Mohammed Ghouse, L. and Nazreen Hassan, S. 2020. Attitude of Farmers towards Crop Diversification. Int.J.Curr.Microbiol.App.Sci. 9(09): 2305-2308.

doi: https://doi.org/10.20546/ijcmas.2020.909.287 